\title{
The legal capacity of child-headed households
}

\author{
by Graham Ritchie
}

The following thoughts form a discussion topic for a multi-disciplinary group. They are not an attempt at legal theory, but are meant to be a signpost for the direction of work to be undertaken by The Institute of Advanced Legal Studies; the Child Rights Unit of the Department of Law, Free State University, South Africa; and The National University of Lesotho.

\section{THE PROBLEM}

$\mathrm{T}$ his paper presents some thoughts on the possible impact on the legal capacity of children orphaned by the aids pandemic in sub-Saharan Africa. Throughout history the human spirit has shown resilience in the face of disheartening and frightening catastrophy in all its myriad forms, and the human mind can adapt to and accommodate the daily and personal actuality of a catastrophy so large that its extent and implications are beyond imagination.

Statistics show the scale and the trends of the aids pandemic, but that evidence in itself is not indicative of the structural changes that society will undergo in consequence of those trends. Without the immediacy of personal experience any consideration of such matters remains theoretical without connection to practical reality. What is the practical situation (personally experienced by many thousands of children) that the law has to be capable of addressing as a result of the aids pandemic?

One reality is that children under the age of legal majority are having to care for themselves and younger siblings. The numbers are so large that state resources and infrastructure cannot begin to provide direct care for those children, who continue to live in their home environment without parents, uncles, aunts, cousins, and often without grandparents. The fact of their survival and ability to adapt is an instance of the resilience and survival instinct of humankind.

Society will have to organise itself to provide protection, food, clothing, shelter, and education to families of children who do not necessarily have the day to day support and guidance of reliable and trustworthy adults. In order to live daily life, the children who have responsibility for themselves and for younger brothers and sisters will have to be equipped with the legal capacity to deal with government, aid agencies, landlords, creditors, suppliers of essentials, employers and all those people and organisations that the adult parents of children would normally have to deal with.

This paper considers the need for children to have the legal capacity to enforce the right to shelter.

\section{THE STATISTICS}

The World Health Organisation (1995) estimates that HIV had infected 15 million people by 1995, of whom one million were children. There is an estimate that there are now 10 million unaccompanied children in sub-Saharan Africa due to HIV, and it is calculated that by 2010 there will be 26 million unaccompanied children in Africa and 41 million unaccompanied children globally. A significant proportion of these children will have dead mothers and fathers.

The 1996 South African Census registers 168,382 children with both parents dead. There are statistics for the Free State, which were compiled from a survey undertaken during 2002 on behalf of the Department of Education. Included within that survey was the information that out of 502,033 learners in the Free State in 2002:

- 15,774 (3.1\%) were on their own without adult supervision and support;

- 74,918 (14.9\%) lived with relatives who were not their parents;

- 106,201 (21.2\%) lived with one parent;

- 105690 (21.1\%) were hungry and in need of assistance.

\section{A NEW LEGAL FRAMEWORK}

Each and every person has the same needs, if not the same expectations of those needs being satisfied. Children need care, food, shelter, protection, stability, and consistent affection. In general, properly functioning family life can provide that, but by no means always as any social worker or family law practitioner can confirm. 
Do children have a right to those needs being satisfied? A normal adult atavistic response is that of course children do. It is only in the latter part of the last century that the notion of children having rights that demand to be satisfied rather than needs that should be provided for as a fundamental moral or atavistic response has emerged. The distinction is that children now have independently standing enforceable rights rather than a moral claim on those whose response is a desire to protect.

In established and stable societies the daily work of a legal practitioner is based on the legal framework under which they operate, and the practice and procedure that has developed within that legal framework. The distinction of whether a child has a right not to be abused, as opposed to an expectation and hope that others will exercise a moral and legal duty to provide protection, is barely relevant to the exercise of legal procedures invoked to attain the well being of that child. The legal practitioner is unlikely to find the distinction particularly relevant for the purposes of managing the case.

In a society in transition, and facing destabilising events, the distinction becomes a matter of fundamental importance to the survival of its children. If the law is established on a child rights basis, then an argument can be made that satisfaction of those rights takes precedence over other legal interests or even rights (see, for example, Susan A Wolfson, Children's Rights: The Theoretical Underpinning of the 'Best Interests of the Child', and Freeman and Veerman, The Ideologies of Children's Rights).

An important theoretical basis to be clear about is when the rights of a child actually accrue to a child. There is the theoretical approach of S I Benn in Human Rights - for whom and for what?, where a right holder is defined as ... "someone aware of himself, not just as a process or happening (as he may be aware of his digestive processes), but as agent, as having the capacity to make decisions that make a difference to the way the world goes ... he is conscious of himself as capable of having projects that constitute certain existing or possible states 'important' or 'unimportant'" (page 404).

This thinking is redolent of the "Gillick competent child" (see below), and has some application to the childheaded household situation. It does not go far enough however, and the approach of John Kleinig is necessary to complete the definition of who qualifies for rights. His view is that a person who is "... capable of having projects" can be a rights claimant because of the need to pursue those projects according to their ability and functionality. A very young or otherwise vulnerable child is not capable of having a project interest, but has needs capable of being labelled "welfare interests".

Kleinig defines these as: “... those interests which are indispensable to the pursuit and fulfillment of characteristically human interests, whatever those interests might be" ("Crime and the Concept of Harm", American
Philosophical Quarterly (1978)). This is summarised by Susan A Wolfson as follows:

"The best answer to the questions concerning who are right holders and what the content of their rights are is that moral (and legal) rights are held by those who have interests, which are in some sense intimately and inextricably bound up with their personalities. We can take 'interests' to mean roughly 'a capacity to be disposed to form conscious plans and projects."

Does this definition exclude very young children? Probably not - the sight of young hungry street children doing what they can to survive shows a capacity "to be disposed to form conscious plans and projects". As for the rights of infants, the Kleinig definition above is sufficient.

\section{CONVENTION AND CONSTITUTION RIGHTS}

Legal practitioners are unlikely to worry unduly about a definition of interests leading to principles of child protection or child rights. The domestic law under which they practice is the framework within which they work, and they will know what the practical objective is for which they strive, whatever the theoretical definition of that objective may be.

Domestic law in established societies uses constitutional and human rights, legislation, and common law as reference points. In transitional societies, international conventions and national constitutions are fundamentally formative and influential in the development of theoretical norms, which have a slow but long term impact on practice and procedure.

\section{Rights derived from conventions and constitutions}

These rights can be traced through from the Universal Declaration of Human Rights (UDHR) down to the practical administration of justice in a district court. For example, the Preamble to the UDHR states that “... recognition of the inherent dignity and of the equal and inalienable rights of all members of the human family is the foundation of freedom, justice and peace in the world ..." This is echoed by the United Nations Convention on the Rights of the Child (UNCRC), which refers in its Preamble to the proclamation made by the UN in the UDHR that ... "childhood is entitled to special care and assistance". Recognition is given to the fact that "in all countries in the world, there are children living in exceptionally difficult conditions, and that such children need special consideration".

The UNCRC places an undertaking on states (in Art 2) to take all appropriate measures to protect the child against all forms of discrimination, including from family members. Article 3 requires the best interests of the child to be a primary consideration for courts of law, administrative authorities and legislative bodies in all actions involving children. Article 20 states that: "A child 
temporarily or permanently deprived of his or her family environment, or in whose best interests cannot be allowed to remain in that environment shall be entitled to special protection and assistance provided by the State.”

These themes are continued in the African Charter on the Rights and Welfare of the African Child (ACRWAC), which notes that the situation of most African children ... "remains critical due to the unique factors of their socioeconomic, cultural, traditional and developmental circumstances, natural disasters, armed conflicts, exploitation and hunger ..." Recognition is given to the unique and privileged position occupied by the child in African society, and the child's need for legal protection resulting from the needs of his physical, mental, moral and social development.

The South African constitution gives every child a right to family/parental care; basic nutrition, shelter, health care services and social services; and the right not to be required to perform work that is inappropriate to the child, or places at risk the child's well being, education, physical or mental health and moral or social development. The child's interests are of paramount importance in every matter concerning the child.

In summary, key matters referred to in the above sources which are relevant to a consideration of the legal capacity of children in the context of child-headed households are:

1. The importance of the family environment.

2. The importance of the best interests of the child as a primary consideration.

3. The recognition that in all countries of the world there are children living in difficult circumstances.

4. The recognition that "the situation of most African children remains critical due to the unique factors ...".

The global, regional, and national convention and national constitutional rights briefly referred to above set the legal framework to the aspirations referred to as rights in those instruments. By their nature the proclamations contained in international conventions and national constitutions are statements of general principle that validate and mandate the satisfaction of the natural human needs of children.

Joachim Wolf in his essay "The Concept of the 'Best Interests' in Terms of the UN Convention on the Rights of the Child" (The Ideologies of Children's Rights, Freeman and Veerman), proposes that "the best interests of the child" within the context of the UN Convention on the Rights of the Child leads to one or other of three possible conclusions which can perhaps be described as:

1. This is a legally binding concept

2. This is a political aspiration.

3. This is a partially coherent concept affected by different national and cultural approaches.
There has been no counter argument to the concept of "best interests" being other than rights based, and so the conclusion of Joachim Wolf is a reasonable one to work from when considering legal capacity of child-headed household issues:

"With the coming into force of the Convention on the Rights of the Child, the 'best interests of the child' has become an international legal concept. For the first time measures and procedural requirements of states which prescribe how they have to exercise their discretion in matters relating to the well-being of children can be tested in terms of an international convention."

In the face of the aids pandemic, it is clear that the law of the legal capacity of children needs to change as a response to social changes.

\section{A BRIEF OVERVIEW OF THE LEGAL CAPACITY OF CHILDREN}

A starting point is that a child is a person under the age of 18 years (UNCRC and ACRWAC).

\section{The law in South Africa}

In South Africa, even though a child is a person under the age of 18 years, a person does not reach the age of majority until 21 . In contrast to common law countries, there are two stages on the road to majority in South Africa. Children are infans and then minor. A child has the legal capacity of an infans from birth to the age of seven years. A child then has the legal capacity of a minor from the age of seven years until the age of majority at the age of 21 years. On the way to majority the child ceases to be a child at the age of 18 years but does not attain the age of majority until 21 years. This framework is likely to change (see the South African Children's Bill).

Factors other than age affect the legal capacity of a person, including domicile, physical and mental disability and illness, illegitimacy, and disqualification through civil or criminal sanction. For the purposes of this paper only the impact of age on legal capacity is considered.

South African family law has developed during a long period of reasonable stability as far as the overall framework of family law is concerned, (although there has been fundamental political and social change in the country). The unavoidable fact is that there is now a catastrophic development that will impact on that slowly developed law. That development is the stark reality that a significant percentage of the overall population will be families of children who live without any care or support from adults either in the immediate family or the extended family because such adults are dead.

\section{The UK, the "competent child" and further cases}

As already mentioned there is an innate reluctance on the part of any legal establishment in any jurisdiction to make abrupt changes in the way that the law is interpreted 
and applied. Two cases can be used to illustrate that. One is an English case of the 1980's and the other is a current case, which started in the jurisdiction of England and Wales and then progressed to the European Court of Human Rights in Strasbourg. That case is now being taken into account in the deliberations of a current Australian case. These cases are just two examples of how the application of law evolves in response to social developments, albeit with many a pause for thought and glance over the shoulder by the judiciary.

The first case is that of Gillick $v$ West Norfolk and Wisbech Health Authority [1986] AC 112. This decision developed the concept of the "competent child" which is now part of the judicial arsenal in England and Wales. The case was also a reminder that the welfare of a child overrides policy considerations; or put another way, the interests of the child are of such paramount importance that those interests take precedence over other considerations such as administrative regulations or even government policy. In a report for the European Commission I completed in 2002 on child protection and the legal capacity of child care worker issues, I labelled that the "overriding principle" for the purposes of the report. That label is suitable for use in the present instance.

Gillick concerned the problem of girls under the age of 16 years receiving contraceptive advice at an age when such sexual activity was unlawful. Another issue arising from that case was whether it was lawful for a medical practitioner to give such advice to an under age girl without first getting the consent of her parents. The House of Lords found that a girl under the age of 16 had the legal capacity to consent to medical examination and treatment, including contraceptive treatment, if she had "sufficient maturity and intelligence to understand the nature and implications of the proposed treatment". The court also held that. .

"That the parental right to control a minor child deriving from parental duty was a dwindling right which existed only in so far as it was required for the child's benefit and protection that the extent and duration of that right could not be ascertained by reference to a fixed age, but depended on the degree of intelligence and understanding of that particular child and a judgment of what was best for the welfare of the child; that the parents' right to determine whether a child under 16 should have medical treatment terminated when the child achieved sufficient intelligence and understanding to make that decision itself..."

This development was similar to that in the United States where schoolchildren were held to be "persons" under the Constitution and their constitutional rights did not just accrue at the age of majority.

In Reg v D [1984] AC 778 the House of Lords held that a child's capacity to make his/her own decision depends upon that child having sufficient understanding and intelligence to make the decision and is not to be determined by reference to any judicially fixed age limit.
This principle could be applied in the context of childheaded households whereby a child head of such a household could be deemed to be not just able to make his/her own decisions, but could be deemed to possess the legal capacity to take on property rights and obligations.

A further case to be considered is the decision by the European Court of Human Rights in Christine Goodwin v The United Kingdom (Application no 28957/95). That case considered alleged violations of Articles 8, 12, 13, and 14 of the European Convention on Human Rights in respect of the legal status of transsexuals in the United Kingdom, and particularly their treatment in the sphere of employment, social security, pensions and marriage. In that case the court "...emphasised the importance of keeping the need for appropriate legal measures under review having regard to scientific and societal development", and reiterated a principle that is identified time and time again in human rights cases: the need to strike a fair balance between the general interest of the community and the interests of the individual.

\section{THE FUTURE}

What has all this got to do with orphaned children in Africa? The answer is a great deal, because to ensure that such children are housed, fed and clothed, established property rights will have to be amended. To achieve that a rights-based approach, (otherwise represented as the “overriding principle"), and the Gillick competent child principles can be used in support of such proposition.

To see why this is necessary, the needs of orphaned children living in child-headed households must be examined. Real life examples are everywhere in subSaharan Africa, and are described in a report Starting From Strengths - Community Care for Orphaned Children in Malawi (final report submitted to the International Development Research Centre (IDRC)). That report was undertaken in response to Malawi's rapidly rising population of children who have lost one or both parents to the HIV/AIDS pandemic sweeping sub-Saharan Africa.

Findings revealed the predominance of local cultural definitions of, and responses to, HIV/AIDS. The extended family and other traditional support structures continue to support most of the children orphaned by AIDS, but the research also underscored the strains on this system and the increasing number of vulnerable children whose rights are not recognised. Some of the children identified in the research as being most at risk include:

1. Children who have experienced multiple loss of people, especially over a short time;

2. Children who have lost their mother;

3. Girls;

4. Children who have experienced many different types of loss (person, environment, property, status);

5. Children who do not have someone they can trust; 
6. Children who are isolated (eg orphan-headed households)

7. The very quiet and reserved child;

8. Teenagers;

9. Very young infants with no parents; and

10. Children with a disability.

The research concludes by making a number of recommendations promoting greater local, national, regional, and international collaboration in supporting children. These recommendations suggest specific strategies falling under the categories of:

1. Building on traditional cultural strengths;

2. Addressing the alleviation of poverty;

3. Promoting a continuum of care;

4. Integrating services;

5. Counteracting "property grabbing”;

6. Supporting children's psychological needs;

7. Arguing for a rights based approach.

The report Starting From Strengths - Community Care for Orphaned Children in Malawi highlights the problem of property grabbing in a real-life account entitled "An orphan's story", which tells how a child-headed family faced pressures from relatives seeking to lay claim to their home and possessions after the death of their parents. Such children need:

1. Their house to be legally theirs whatever outside claims on that house maybe.

2. If the head of the household is under the age of adulthood, he/she needs to have the legal capacity to interact with the state as a legal adult on behalf of themselves and the younger children for whom they care to obtain welfare benefits in the form of money, health benefits, education, and legal protection from predators.

3. Where possible the head of the household should be able to interact with aid agencies, social welfare departments, and suppliers of food, fuel and water.

The International Red Cross recommend that parents who know that they are about to die should make wills to ensure that the children benefit from use of the family property. The making of a will does not solve the entire problem however because the children may not benefit from it. For example, the beneficiary of the will maybe an uncle/aunt or some other adult who has lent money to the parents provided that the family property is passed to that other adult. It may not be possible to pass the family property to the children because that property is charged to a bank or other creditor.

How can the children avoid being made homeless in such a situation? The overriding principle that the interests of the children are of paramount importance, the "best interests" right in the UN Convention on The Rights of the Child, and the Gillick "competent child" arguments can be deployed.
The needs of children in Southern Africa are recognised, and have attracted responses in The Children's Bill and cases such as Republic of South Africa \&others $v$ Grootboom (“Grootboom”) 2001(1) SA 46 (CC), 2000(11) BCLR 1169 (CC).

\section{South Africa: The Children's Bill}

A number of important measures directly relevant to child-headed households are contained in the Bill, including:

- A provincial head of social development may recognise a household as child-headed if the parent or primarycare giver is terminally ill or dead, no adult family member is available to care for the children, and a child has assumed the role of primary care-giver in respect of a child/children in the household;

- A child-headed household must function under the supervision of an adult designated by a child and family court or other approved body;

- The designated adult may collect state benefits to which the household is entitled, and must consult with the child at the head of the household (and others if they are old enough) before taking decisions which affect them;

- The child-head of household may take day-to-day decisions relating to the household and the children in it, subject to the supervision and advice of the adult person concerned;

- A child-headed household may not be excluded from any form of state relief for poor households solely because it is child-headed;

- Every child who owns property has the right to the administration of that property in his/her best interests;

- State bodies and employees and anyone else in authority with official control over a child must adhere to the "best interest" principle - ie that the child's best interest is of paramount importance.

The Children's Act will take precedence over other legislation, thus reflecting the overriding principle of child rights.

\section{CONCLUDING THOUGHTS}

In practice in the 1980's I was able to obtain the support of individual judges in particular cases in varying the property rights of parents by transferring those property rights to the children on the basis of the "overriding principle". Under the law of England and Wales, those children could not directly hold that property and the property was therefore held by the Court of Protection and administered by a nominated adult. Property which belonged to the father of an illegitimate child was transferred to the mother of that illegitimate child on the same basis during the 1990s.

Subsequent courts considered that to be too radical, and the practice is now that property transferred from the father of an illegitimate child to the mother of that child, or directly for the use of that illegitimate child, should only 
be used for the benefit of the child during his/her minority. Once that child has attained majority, the property, or capital used for the benefit of the child during their minority, should be returned to the father.

Within these cases lies a clue to the preservation of housing, at least for child-headed households. Judicial practice or legislation could ensure that the orphaned children of any householders would have pre-emptive property rights over that property until the youngest child of the family attains their majority. It is only then that any legatee or mortgagee can obtain the property for their (or their successors') use.

Changes in judicial practice and/or legislation can be justified on the need to adapt the law in the face of society's changing needs. The adaptation of the law would be on the basis of the overriding principle that the interests and welfare of children is of paramount importance which would tip the balance that has to be struck between the general interest of the community and the interests of the individual in favour of the child/children. In the situation under consideration there can be no conflict between the child as individual and the community because the best interests of child-headed households coincide with the best interests of the community.

The conflict between the child-headed household and legatees or mortgagees is resolved by a provision that once the youngest child of the child-headed household attains the age of majority the legatee or mortgagee can exercise their deferred property rights and can enter into their property. Where ownership of family property is unclear the overriding principle would operate to defer any third party claims on that property until the youngest child of a child-headed household attains majority.

The Gillick concept of the competent child is relevant here because if a child is looking after their younger brothers and sister (even if that is very hard for them), that child is showing a sufficient level of maturity for the law to deem that child to be able to take on a legal capacity normally allowed to adults to enable that child to undertake their family responsibilities. The rights-based approach determines that the housing needs of each child of the child-headed household, (whether Gillick-competent or not) must be satisfied as a priority over any other conflicting interests and claims.

The preservation of any family housing will be one major factor in ensuring the convention and constitutional rights of children living in child-headed households. 숭

\section{Graham Ritchie}

Solicitor; Director, International and Professional Training and Research

Unit, Institute of Advanced Legal Studies, University of London

\section{SALS Lectures}

Thursday, 2 October

\section{TIMOTHY SPANGLER}

Partner, Berwin Leighton Paisner

The UK's new approach to collective investment schemes: an international perspective

Thursday, 9 October, $6 \mathrm{pm}$

Lecture at Oxford Brookes University on banking regulation in association with Oxford Brookes University and the Journal of International Banking Regulation

(details to follow)

Thursday, 6 November

\section{MICHAEL TUGENDHAT QC}

5 Raymond Buildings

Privacy and celebrity

(this updates the speaker's highly successful SALS lecture on the same subject given in May 2001)

Thursday, 4 December

\section{BEN BRANDON}

Partner, Russell Jones \& Walker

30 years of anti-terrorist legislation
Thursday, 22 January 2004

Lecture on banking regulation in association with Oxford Brookes University and the Journal of International Banking Regulation

(to be held at Charles Clore House, details to follow)

\section{Other events}

Wednesday, 12 November 2003

Seventh SALS Annual Dinner

Middle Temple Hall

Thursday, 20 November

Half day seminar on the Planning \& Compulsory Purchase Bill

To be given by the SALS Planning and Environmental Law Reform Working Group

(times and details to follow).

Booking is requested for all events, which take place at the Institute of Advanced Legal Studies, 17 Russell Square, London WC1, unless otherwise stated. Please contact the SALS office (tel: 0207862 5865; email: sals@sas.ac.uk) for further information. 